\title{
Distribution Models of Timber Species for Forest Conservation and Restoration in the Andean-Amazonian Landscape, North of Peru
}

\author{
Dany A. Cotrina Sánchez ${ }^{1, *(\mathbb{D})}$, Elgar Barboza Castillo ${ }^{1}\left(\mathbb{D}\right.$, Nilton B. Rojas Briceño $^{1}{ }^{\mathbb{D}}$, \\ Manuel Oliva ${ }^{1}{ }^{1}$, Cristóbal Torres Guzman $^{1}$, Carlos A. Amasifuen Guerra ${ }^{2}{ }^{\circledR}$ and \\ Subhajit Bandopadhyay ${ }^{3}$ (1) \\ 1 Instituto de Investigación para el Desarrollo Sustentable de Ceja de Selva (INDES-CES), \\ Universidad Nacional Toribio Rodríguez de Mendoza de Amazonas, Chachapoyas 01001, Peru; \\ ebarboza@indes-ces.edu.pe (E.B.C.); nrojas@indes-ces.edu.pe (N.B.R.B.); soliva@indes-ces.edu.pe (M.O.); \\ cristobal.torres@untrm.edu.pe (C.T.G.) \\ 2 Centro Experimental La Molina, Dirección de Recursos Genéticos y Biotecnología, Instituto Nacional de \\ Innovación Agraria (INIA), La Molina 15012, Lima, Peru; camasifuen@inia.gob.pe \\ 3 Department of Ecology and Environmental Protection, Poznan University of Life Sciences, Piatkowska 94, \\ 60-649 Poznan, Poland; subhajit.bandopadhyay@up.poznan.pl \\ * Correspondence: alexander.cotrina@untrm.edu.pe; Tel.: +51-976-010-315
}

Received: 13 August 2020; Accepted: 19 September 2020; Published: 25 September 2020

\begin{abstract}
The Andean-Amazonian landscape has been universally recognized for its wide biodiversity, and is considered as global repository of ecosystem services. However, the severe loss of forest cover and rapid reduction of the timber species seriously threaten this ecosystem and biodiversity. In this study, we have modeled the distribution of the ten most exploited timber forest species in Amazonas (Peru) to identify priority areas for forest conservation and restoration. Statistical and cartographic protocols were applied with 4454 species records and 26 environmental variables using a Maximum Entropy model (MaxEnt). The result showed that the altitudinal variable was the main regulatory factor that significantly controls the distribution of the species. We found that nine species are distributed below $1000 \mathrm{~m}$ above sea level (a.s.l.), except Cedrela montana, which was distributed above $1500 \mathrm{~m}$ a.s.1., covering $40.68 \%$. Eight of 10 species can coexist, and the species with the highest percentage of potential restoration area is Cedrela montana (14.57\% from Amazonas). However, less than $1.33 \%$ of the Amazon has a potential distribution of some species and is protected under some category of conservation. Our study will contribute as a tool for the sustainable management of forests and will provide geographic information to complement forest restoration and conservation plans.
\end{abstract}

Keywords: Amazon; maximum entropy; timber; species distribution; forest recovery; Peru

\section{Introduction}

The Amazon is the most extensive and widely distributed forest region (approximately 70 million hectares) and is subjected to permanent forest resource extraction in Peru [1]. The Peruvian Amazonia comprises $60 \%$ of the country and is marked by a large degree of floral diversity. The floral activities are unique in nature in the fragile and complex ecosystem of the Andean-Amazonian transitional landscape [2]. In most forests, selective logging focuses on harvesting only specific individual trees of high commercial value $[3,4]$. In this way, it is a direct cause of deforestation and indirectly promotes shifting agriculture, which it makes a hurdle towards sustainable forest management for the Peruvian Amazon [5]. 
In this regard, species distribution modeling (SDM) technique has been used for the mapping of flora and fauna distribution by combining species data along with multiple environmental factors, such as bioclimatic, distance, and/or topography factors, etc. Such diversity modeling will help for predicting and estimating the map of presence as well as the monitoring of the species over a larger area over time [6-8]. In this way, SDM allows for the analysis of a variety of situations related to the geographical distribution of species, such as: (1) rare or endangered species distribution, (2) current areas that should promote the conservation of a set of species, (3) identifying the most cost-effective places to establish new species populations, and 4) the predicted distribution of these species in the future under global warming and climate change $[9,10]$. For such reasons, SDM aims to more effectively and generously support conservation actions [11] by predicting possible fragmentation or reduction in potential forest areas under future climate change scenarios [12].

In recent years, predictive SDM has become an increasingly important tool for ecosystem conservation management and for restoration action plans $[9,10,13]$. As such, SDM provides a tool for mapping habitats and producing credible, supportable, and replicable information by contributing to species conservation and management decision-making. In this study, we established the current and potential distribution of species using occurrence data through a Maximum Entropy (MaxEnt) model [14]. MaxEnt has been widely applied to studies of flora conservation [15], fauna [16,17], management of endangered species [18,19], conservation of endemic species [20], and invasive species control [21,22], as well as in forestry and agricultural zoning [12,23] [24] from local to global scales, allowing the development of "species distribution" maps and, finally, the estimation of a "suitability index" [25] for the Peruvian Amazon region. Though a few studies have been done over the Amazon region using MaxEnt models for evapotranspiration estimation [26], fire probability distribution [27], infrastructure expansion [24], and conservation of freshwater turtles [11], no such studies have been conducted for species distribution and its spatial modeling, which are the prime focuses of all conservation and restoration policies.

SDM permits suitability modeling of habitat pathways for endangered species and intervention in the soil to protect and expand tree species distributions [28]. Tree species distributions can be located in areas that have been degraded, but some of them have potential for restoration by installing native wood species $[29,30]$ through active and effective restoration measures that allow the restoration of forest ecosystems with their functions and biodiversity [31]. Planting native tree species is the predominant restoration strategy for accelerating the succession of forests on depleted lands [32-34] in order to restore areas where forests have been reduced by natural (landslides and winds) or anthropogenic causes [35]. Planting a variety of native forest species is desirable for multiple reasons, including the conservation of biodiversity [36] through restoration activities such as afforestation, reforestation, natural regeneration, and assisted regeneration [37], thus contributing to the development of successful restoration projects [38,39].

This study, therefore, seeks to determine the volume of timber harvested in Amazonas, Peru by identifying the ten most exploited forest species, namely Apuleia leiocarpa (Vogel) J.F. Macbr., Calycophyllum spruceanum (Benth.) Hook. f. ex K. Schum., Cariniana decandra Ducke, Cedrela montana Moritz ex Turcz., Cedrela odorata L., Cedrelinga cateniformis (Ducke) Ducke, Ceiba pentandra (L.) Gaertn., Hura crepitans L., Inga sp., and Otoba parvifolia (Markgr.) A.H Gentry by using a unique MaxEnt modeling technique. This study will then model the potential distribution of each species and identify degraded areas for restoration through afforestation or reforestation. Finally, our study developed an SDM based the MaxEnt modeling tool for the recovery of forests and the conservation of natural resources in the Peruvian Amazon. 


\section{Materials and Methods}

\subsection{Study Area}

The Peruvian Amazon is located in the Andean-Amazonian landscape of northern Peru. This part of the Amazon is mainly characterized by premontane, montane cloud, and lowland forest [2], and is also marked by altitude, which represents a wide variety of fauna and flora diversity [40]. There are many emerging tree species in this region, such as Cedrelinga, Cedrela, Buchenaria, Dipteryx, Sloanea, and Podocarpus; underneath emerging trees lie species like Hevea, Hernandia, Calophyllum, Qualea, and Inga [41]. The region covers an area of approximately 39.2 thousand $\mathrm{km}^{2}$ of rugged territory (Figure 1). The study area is located between the parallels $3^{\circ} 0^{\prime} 15^{\prime \prime}$ and $7^{\circ} 2^{\prime} 0^{\prime \prime}$ south and the meridians $77^{\circ} 0^{\prime} 15^{\prime \prime}$ and $78^{\circ} 42^{\prime} 15^{\prime \prime}$ west, with an altitudinal gradient that ranges from $120 \mathrm{~m}$ above sea level (a.s.l.) in the north to $4400 \mathrm{~m}$ a.s.l. in the south. The region shares a border on the east side with the Loreto region, on the west side with the Cajamarca region, on the south side with the San Martín and La Libertad regions, and on the north side with the Ecuadorian territory [42].
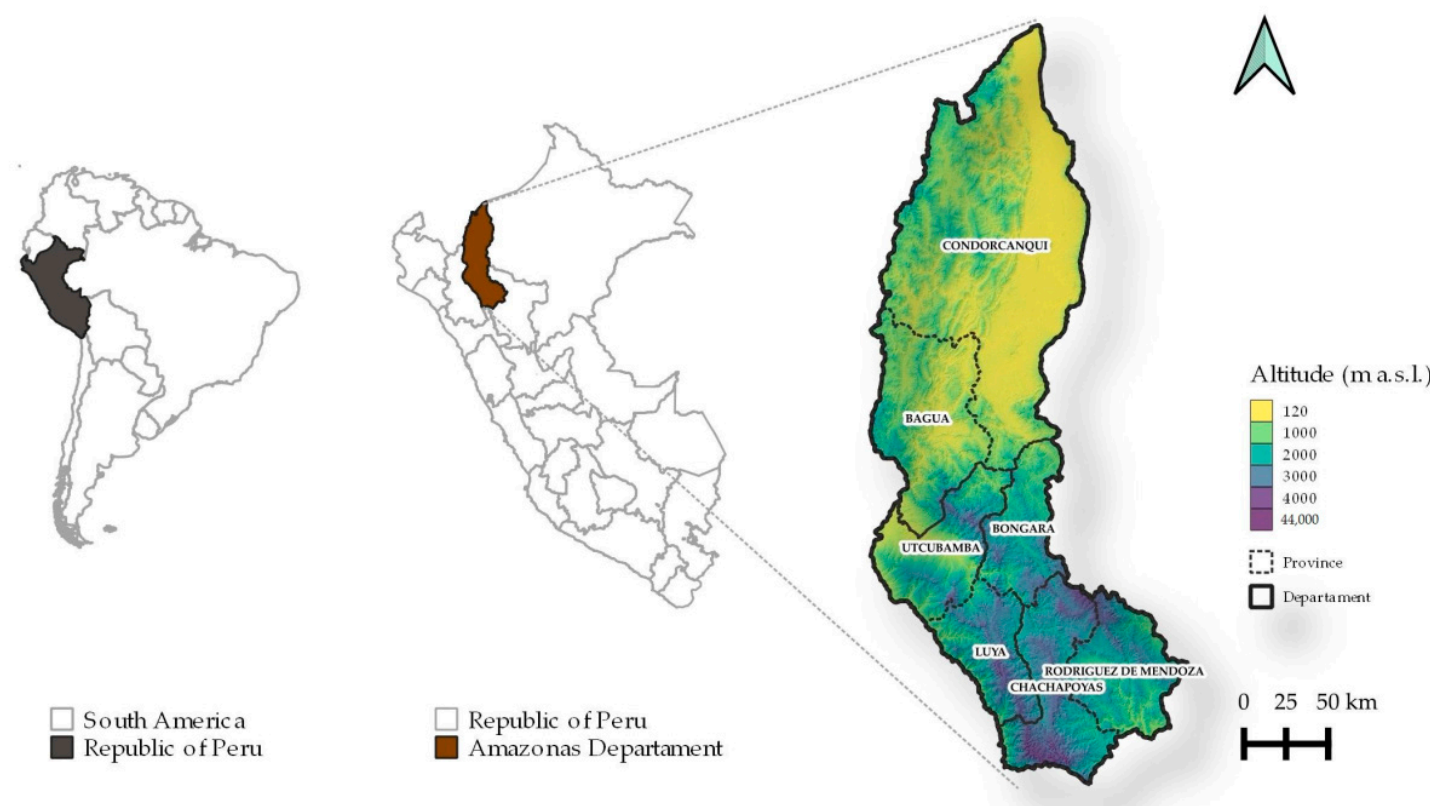

Figure 1. Location of the Amazonas Region in Peru.

\subsection{Methodological Design}

We adapted the methodologies proposed by OSINFOR [43] and Hengl et al. [44] and applied by Rojas et al. [45] to assess the biogeographical distribution of the ten forest timber species. The detailed methodological framework adopted by this study is shown in Figure 2. From the perspective of management practices and forest exploitation plans granted for the Amazonas region, we selected ten (10) species that have been highly exploited and unrooted over time [46]. The cartography for environmental variables was obtained and homogenized from the WorldClim web portal (http://worldclim.org/version2). The soil variables were obtained from SoilGrids ver. 0.5.3 (http://soilgrids.org), and the physiographic variables were obtained from the United States Geological Survey (USGS) (http://srtm.usgs.gov). The collected datasets were grouped according to their contribution to the modeling. 


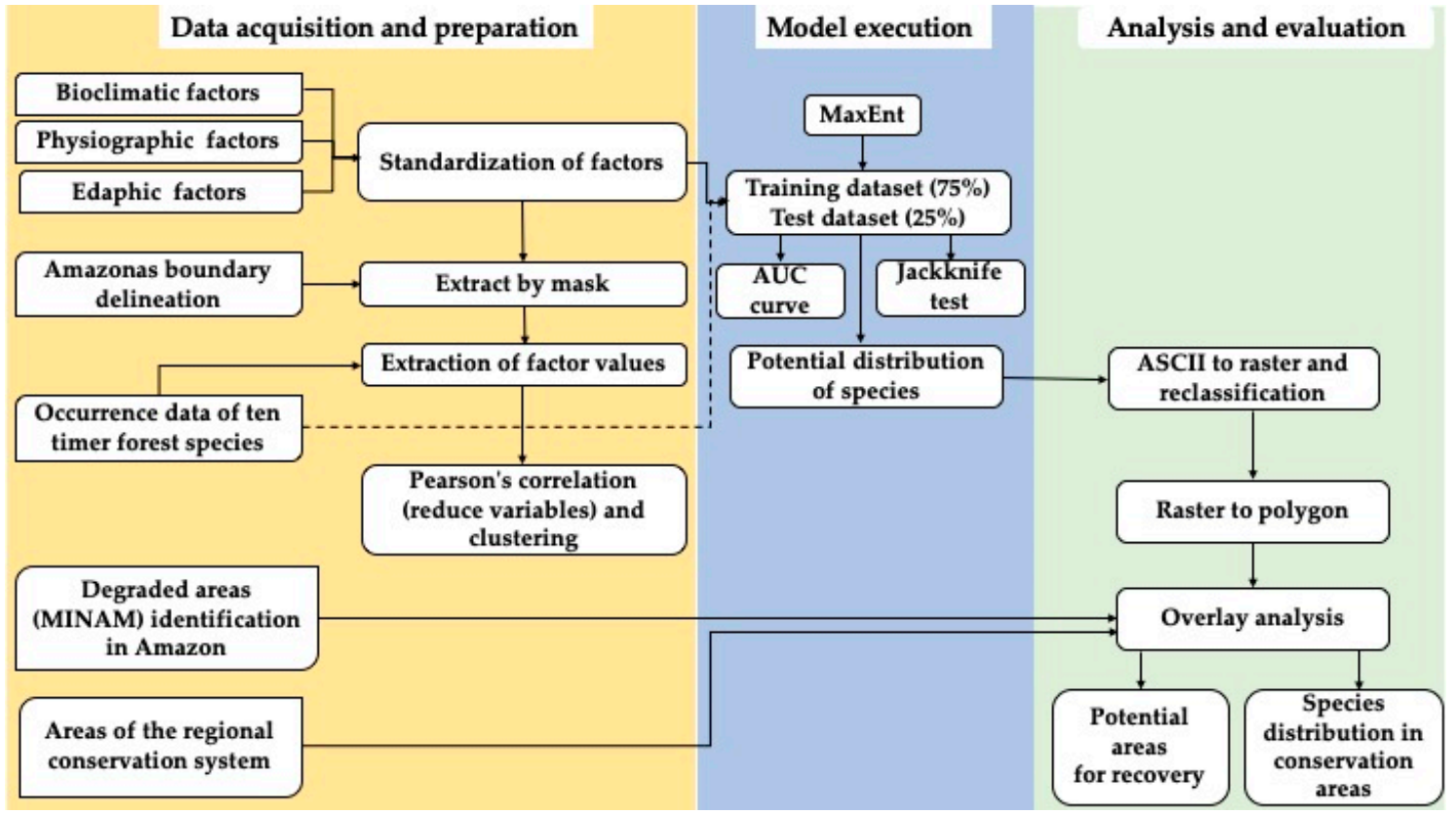

Figure 2. Methodological Process for the Biogeographical Modeling of Timber Species in the Amazonas Region.

In this study, we adopted an SDM-based MaxEnt approach to represent the spatial distribution of the ten most exploited timber species in Amazonas, Peru. Finally, all potential distribution areas obtained were overlapped with degraded areas identified by the Ministry of the Environment (http://geoservidor.minam.gob.pe) for validation. This study was done in an effort to obtain the areas for restoration. Likewise, overlapping was done with natural areas protected by the Peruvian state (http://geo.sernanp.gob.pe) in order to establish the species distribution in conservation areas at the local, regional, and national scale.

\subsection{Selection and Collection of Occurrences of the Most Important Forest Species in the Amazonas Region}

The ten most exploited timber species in the region were identified, taking as a starting point the entry into force of Law No. 29763 (LFFS, October 1, 2015) until 2019. Data on forest species occurrence were collected using a global positioning system (GPS) to provide the locations of timber trees prior to their use. However, species grown in plantations and/or gardens were not considered [47-49]. There was a total of 4454 recorded units of data for the 10 species of interest, which were subsequently systematized to meet the MaxEnt requirements. The ten timber species with the greatest demand during 2016-2019 were given volume in round cubic meters (Vol. $\mathrm{m}^{3}(\mathrm{r})$ ) (Table 1; Supplementary Table S1). Of these 10 species, five were evaluated by Rojas et al. [45] as being the most exploited in 2018. However, in this study, in addition to the restoration approach, they were analyzed under a system of conservation and coexistence among a greater number of species. In addition, the species under study are in different statuses of conservation (Table 1) in the IUCN (International Union for Conservation of Nature) Red List of Threatened Species (https://www.iucnredlist.org/). 
Table 1. Number of Records Used for Biogeographic Modeling of the 10 Timber Species and The Timber Volume Granted for Use from 2016 to 2019.

\begin{tabular}{|c|c|c|c|c|c|c|}
\hline $\mathrm{N}^{\mathrm{o}}$ & Species & Local Name & Family & Conservation Status ${ }^{1}$ & Records Number & Vol. $\mathrm{m}^{3}(\mathrm{r})$ \\
\hline 1 & $\begin{array}{l}\text { Cedrelinga } \\
\text { cateniformis }\end{array}$ & Tornillo & Fabaceae & $\mathrm{LC}$ & 2193 & $20,786.22$ \\
\hline 2 & Otoba parvifolia & Sempo & Myristicaceae & NL & 414 & 1264.81 \\
\hline 3 & Ceiba pentandra & Lupuna & Malvaceae & $\mathrm{LC}$ & 333 & 8144.38 \\
\hline 4 & Inga sp. & Guabilla & Fabaceae & NL & 311 & 1125.54 \\
\hline 5 & Apuleia leiocarpa & Anacaspi & Fabaceae & NL & 241 & 1608.01 \\
\hline 6 & Cedrela montana & Cedro & Meliaceae & EN & 215 & 2952.86 \\
\hline 7 & Cariniana decandra & Papelillo & Lecythidaceae & NL & 210 & 2120.07 \\
\hline 8 & $\begin{array}{l}\text { Calycophyllum } \\
\text { spruceanum }\end{array}$ & Capirona & Rubiaceae & NL & 201 & 877.16 \\
\hline 9 & Cedrela odorata & $\begin{array}{l}\text { Cedro } \\
\text { amargo }\end{array}$ & Meliaceae & VU & 184 & 579.57 \\
\hline 10 & Hura crepitans & Catahua & Euphorbiaceae & NL & 152 & 1569.96 \\
\hline \multicolumn{5}{|c|}{ Total } & 4454 & $37,686.17$ \\
\hline
\end{tabular}

${ }^{1}$ LC: Least concern; NL: Not listed; EN: Endangered; VU: Vulnerable.

\subsection{Basic and Thematic Cartography Conditioning}

Cartographic information on political-administrative boundaries within the district, province, and region was obtained from the National Geographic Institute's (IGN) Fundamental Geospatial Data Infrastructure (https://www.idep.gob.pe). The georeferenced records of the ten species and the cartographic information were projected to a system of geographic coordinates in WGS 84 using Open Source QGIS version 3.8 Zanzibar (https://qgis.org/es/site/).

\subsection{Bioclimatic, Soil, and Physiographic Variables}

The spatial distribution of species within the landscape is based on differential selection of environmental factors that interact and favor their optimal development [50]. In this context, 26 environmental variables were selected, including 19 bioclimatic variables, 3 topographic variables, 3 soil property variables, and solar radiation information (Table 2). The bioclimatic information and solar radiation layers were obtained from the WorldClim (http://worldclim.org/version2) portal. This version of WorldClim provides a spatially interpolated monthly climate data set for global land areas, with a spatial resolution of $1 \mathrm{~km}$. These variables were aggregated over a time range from 1970 to 2000 (30 years) and from 9000 weather stations and 60,000 satellite coverages [51]. The topographic variables were derived from the $90 \mathrm{~m}$ spatial resolution Shuttle Radar Topography Mission (SRTM) Digital Elevation Model (DEM), which was obtained from the United States Geological Survey (USGS) web portal (http://srtm.usgs.gov). The spatial information of physical and chemical soil properties was obtained from SoilGrids version 0.5.3 (http://soilgrids.org) with a resolution of $250 \mathrm{~m}$. This information was generated from 150,000 soil profiles and from 158 covariates obtained from remote sensing using a set of automatic learning methods: random forest with gradient boosting and/or multinomial logistic regression [44].

The cartographic conditioning of the environmental variables and the species records were worked at a standardized spatial resolution of $250 \mathrm{~m}$. The management of the post-modeling spatial information was carried out in the open source GIS software QGIS ver. 3.10. 
Table 2. Bioclimatic, Soil, and Physiographic Variables per Species Used in the Maximum Entropy (Maxent) Modeling.

\begin{tabular}{|c|c|c|c|c|}
\hline Category & Variable & Description & Units & Species ${ }^{1}$ \\
\hline \multirow{13}{*}{ Bioclimatic } & Bio01 & Annual Mean Temperature & ${ }^{\circ} \mathrm{C}$ & \\
\hline & Bio02 & Mean Diurnal Range (monthly mean (max temp-min temp)) & ${ }^{\circ} \mathrm{C}$ & $\mathrm{d} ; \mathrm{g}$ \\
\hline & Bio03 & Isothermality $(($ Bio02/Bio07 $) \times 100)$ & $\%$ & $\mathrm{a} ; \mathrm{b} ; \mathrm{c} ; \mathrm{f} ; \mathrm{g} ; \mathrm{h} ; \mathrm{i} ; \mathrm{j}$ \\
\hline & Bio05 & Max Temperature of Warmest Month & ${ }^{\circ} \mathrm{C}$ & \\
\hline & Bio06 & Min Temperature of Coldest Month & ${ }^{\circ} \mathrm{C}$ & $\mathrm{d}$ \\
\hline & Bio07 & Annual Temperature Range (Bio05-Bio06) & ${ }^{\circ} \mathrm{C}$ & \\
\hline & Bio10 & Mean Temperature of Warmest Quarter & ${ }^{\circ} \mathrm{C}$ & a \\
\hline & Bio11 & Mean Temperature of Coldest Quarter & ${ }^{\circ} \mathrm{C}$ & \\
\hline & Bio12 & Annual Precipitation & $\mathrm{mm}$ & \\
\hline & Bio13 & Precipitation of Wettest Month & $\mathrm{mm}$ & i \\
\hline & Bio14 & Precipitation of Driest Month & $\mathrm{mm}$ & \\
\hline & Bio19 & Precipitation of Coldest Quarter & $\mathrm{mm}$ & $\mathrm{d}$ \\
\hline & Rad & Solar Radiation & $\mathrm{kJ} \mathrm{m}^{-2}$ day $^{-1}$ & $e ; f ; g ; h ; j$ \\
\hline \multirow{3}{*}{ Topographic } & Elevation & Elevation & $\mathrm{m}$ & $\mathrm{a} ; \mathrm{b} ; \mathrm{c} ; \mathrm{d} ; \mathrm{e} ; \mathrm{f} ; \mathrm{g} ; \mathrm{h} ; \mathrm{i} ; \mathrm{j}$ \\
\hline & Slope & Slope & $\circ$ & $a ; e ; i ; j$ \\
\hline & Aspect & Cardinal Slope Direction & $\circ$ & $\mathrm{a} ; \mathrm{b} ; \mathrm{c} ; \mathrm{e} ; \mathrm{f} ; \mathrm{g} ; \mathrm{i} ; \mathrm{j}$ \\
\hline \multirow{3}{*}{ Soil } & $\mathrm{pH}$ & $\mathrm{pH} \times 10$ to $0.30 \mathrm{~m}$ & $\mathrm{KCl}$ & $\mathrm{a} ; \mathrm{c} ; \mathrm{d} ; \mathrm{e} ; \mathrm{f} ; \mathrm{g} ; \mathrm{h} ; \mathrm{i}$ \\
\hline & CIC & Cation Exchange Capacity (at pH 7) $0.30 \mathrm{~m}$ & $\mathrm{cmol}_{\mathrm{C}} \mathrm{kg}^{-1}$ & $a ; b ; c ; f ; g ; i ; j$ \\
\hline & $\mathrm{CO}$ & Soil Organic Carbon Stock (fine-grained soil fraction) to $0.15 \mathrm{~m}$ & $\mathrm{~g} \mathrm{~kg}^{-1}$ & b; $\mathrm{e} ; \mathrm{f} ; \mathrm{h} ; \mathrm{j}$ \\
\hline
\end{tabular}

${ }^{1}$ (a) A. leiocarpa; (b) C. spruceanum; (c) C. decandra; (d) C. montana; (e) C. odorata; (f) C. cateniformis; (g) C. pentandra; (h) H. crepitans; (i) Inga sp; (j) O. parvifolia.

\subsection{Extraction of Values of Climatic, Soil, and Physiographic Variables}

SDMs are widely used to predict the distribution of a species across geographic space and time using environmental data. However, this has generated new concerns regarding inaccuracies and lack of understanding. To address these issues, MaxEnt takes advantage of the existing collinearity to find the best set of parameters. Collinearity between environmental variables can cause certain problems in terms of model over-adjustment, increased uncertainty, and decreased statistical significance $[52,53]$. Therefore, for each species, variables to be excluded from the initial model were determined in order to have a second and final application of the MaxEnt model. In this way, the "Analysis of variable contributions" table was constructed with the 26 inaugural variables and was supported by the results of a "Jackknife" analysis. This analysis allowed the model to be run by excluding each of the variables at a certain time. The variable that considerably affected the model's efficiency at the time of being excluded from the model was considered important [14].

\subsection{Variable Correlation and Clustering}

Pearson's correlation coefficients (r) between the 19 bioclimatic variables, 3 topographic variables, 3 soil variables, and solar radiation were calculated in the R software (version 3.6) for multi-collinearity tests. The variables whose correlation coefficients were greater than 0.8 were eliminated not only to avoid the violation of statistical assumptions, but also to avoid model predictions induced by multi-collinearity between variables [54-57]. First, values of Euclidean distances were introduced from value extraction through the k-means classification tool using the factoextra package. This determined the optimal number of variable groups for each forest species, dividing the data sets into meaningful classes [58]. Dendrograms were then constructed to group climatic, topographic, and soil variables that shared similar characteristics, whereas those with different characteristics were separated into another group. This was done prior to MaxEnt modeling, which used the variables with the greatest contributions to the final model. 


\subsection{Model Execution}

The potential distribution model for each species were generated by a machine learning algorithm based on the maximum entropy principle [14] using the open-source software MaxEnt ver. 3.4.1 (https://biodiversityinformatics.amnh.org/open_source/maxent/). This algorithm estimates the probability of potential distribution of each species, taking into account that the best prediction is obtained by maximizing the entropy of that distribution under certain environmental contexts [14]. The maximum entropy principle was first expounded by E. T. Jaynes, who also discussed its theoretical and mathematical background [59].

For model validation, random data corresponding to the presence records of each species were selected, where $75 \%$ for training and $25 \%$ for model validation were considered, respectively [14]. The algorithm was run using 10 replicates in 5000 iterations with different random partitions (cross-validation method), a convergence threshold of 0.00001, and 10,000 maximum background points. Other settings (e.g., extrapolation, drawing graphs, etc.) were kept as default [21], since MaxEnt is able to select the appropriate function for the number of samples used for a model [25,60].

Subsequently, the model output was validated based on the area under the curve (AUC) $[14,61]$ calculated from the receiver operating characteristic (ROC) [62]. According to the AUC values, five performance levels are differentiated [14,61,63]: excellent $(>0.9)$, good $(0.8-0.9)$, accepted $(0.7-0.8)$, bad (0.6-0.7), and non-valid $(<0.6)$. The main advantage of this method is, in fact, its threshold independence and the objectivity of the results [64]. Therefore, we used the logistic output format to obtain the current models of the ten species evaluated [65]. This format allowed the generation of a map of continuous probability values for the distribution in a range from 0 to 1 . Furthermore, these values were reclassified into four ranges [66]: (1) "high" potential habitat (>0.6), (2) "moderate" habitat (0.4-0.6), (3) "low" habitat (0.2-0.4), and (4) "non-potential" habitat $(<0.2)$. In addition, to assess coexistence, we intersected the high potential distribution among the ten species. The result was reclassified into high ( $>6$ species), moderate (4-6), and low (1-3) coexistence. Similarly, degraded areas were intersected with the coexisting distribution of species, identifying high ( $>6$ species), moderate (4-6), and low (1-3) levels, with potential to be restored with the species under study.

\subsection{Identification of Potential Areas for Conservation and Restoration}

In this stage, the layers of potential forest species areas were superimposed on the map of degraded areas of Peru [67]. This map identified four degradation classes grouped into three degradation categories: "low" (forest fragments), "medium" (negative Net Primary Productivity (NPP) and forest fragments, negative NPP, or changes in vegetation cover), and "high" (deforestation 2001-2017). This analysis made it possible to obtain the potential areas for restoration using forest species throughout the study area. Likewise, the layer of potential areas was superimposed on Amazonas's natural protected areas in their different categories (natural protected areas, reserve areas, private conservation areas) (http://geo.sernanp.gob.pe/geoserver/principal.php), and the conservation concessions granted by the Executive Directorate of Forest and Wildlife Management (DEGBFS) and the Regional Conservation Areas (RCAs) administered by the Amazonas Regional Government, as well as the cartographic information available in the Amazonas Regional Government's Spatial Data Infrastructure (IDER) platform (http://geoportal.regionamazonas.gob.pe), were also included.

\section{Results}

\subsection{Biographical Distribution of Timber Species}

The MaxEnt model was applied to the 10 timber species with a cumulative contribution of $>65 \%$ of only three environmental variables, highlighting the contributions for the modeling of the species C. montana $(98.9 \%)$, C. decandra (93.8\%), and C. spruceanum (90\%), which were mainly driven by the topographic variable "elevation" (Table 3). Likewise, the Jackknife test obtained for each model 
showed that the variables elevation (DEM) and Bio 18 (Precipitation of Warmest Quarter) contributed independently in the largest number of models of the species (Supplementary Figures S11-S20).

Table 3. The Three Main Variables with Major Contributions to the Maxent Modeling of Ten Forest Species in Amazonas, Peru.

\begin{tabular}{ccccc}
\hline Species & Variable 1 (\%) & Variable 2 (\%) & Variable 3 (\%) & Total Contribution \\
\hline A. leiocarpa & Elevation (70.1) & Bio 16 (12.5) & Bio 10 (5.4) & $88 \%$ \\
C. spruceanum & Elevation (60.5) & Bio08 (24.2) & Aspect (5.3) & $90 \%$ \\
C. decandra & Elevation (56.6) & Bio 09 (25.1) & Bio 16 (12.1) & $93.8 \%$ \\
C. montana & Bio 19 (78.4) & pH (15.4) & Bio 02 (5.1) & $98.9 \%$ \\
C. odorata & Bio08 (45.7) & Elevation (24.7) & Rad (15.5) & $85.9 \%$ \\
C.cateniformis & Elevation (47.6) & Bio 18 (21.1) & Bio 09 (9.6) & $78.3 \%$ \\
C. pentandra & Elevation (61.5) & Bio 01 (11.6) & Rad (10.9) & $84 \%$ \\
H. crepitans & Bio 04 (38.8) & Elevation $(23.5)$ & Bio 08 (14.1) & $76.4 \%$ \\
Inga sp. & Elevation (22.7) & Cic (22.4) & Bio 17 (19.9) & $65 \%$ \\
O. parvifolia & Elevation (48.3) & Bio 18 (19.4) & Bio 04 (9.3) & $77 \%$ \\
\hline
\end{tabular}

\subsection{Model Performance}

As a result, there were ten biogeographic distribution models, each corresponding to the timber species under study. Indeed, the average yield of nine out of the 10 species showed AUC $>0.9$, reflecting excellent predictive performance of the models $[19,57,59]$, except for $C$. montana, which was rated as good $(0.8<$ AUC $<0.9)$. The mean AUC values reported for the 10 species ranged from 0.868 (the lowest) to 0.985 (the highest) (Table 4).

Table 4. Maxent Model Performance of Ten Timber Species in Amazonas, Peru.

\begin{tabular}{cccccc}
\hline Species & A. leiocarpa & C. spruceanum & C. decandra & C. montana & C. odorata \\
\hline AUC & 0.954 & 0.985 & 0.958 & 0.868 & 0.985 \\
\hline Species & C. cateniformis & C. pentandra & H. crepitans & Inga sp. & O. parvifolia \\
\hline AUC & 0.914 & 0.952 & 0.977 & 0.965 & 0.948 \\
\hline
\end{tabular}

Under current edaphoclimatic conditions, the general climatic suitability (sum of "high", "moderate", and "low" potential habitat) for the ten timber species under study was mainly distributed in the northern part of the Amazonas region, which includes the Bagua and Condorcanqui provinces. On the other hand, we found that the $C$. montana species were located in the central and southern parts of Amazonas. Figure 3b-k shows the biogeographical distribution areas of ten timber species. In the same distribution context, the species $C$. cateniformis and O. parvifolia present a greater distribution high in the northern part of the study area. 


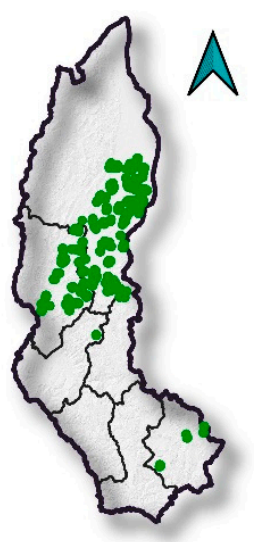

(a) Presence

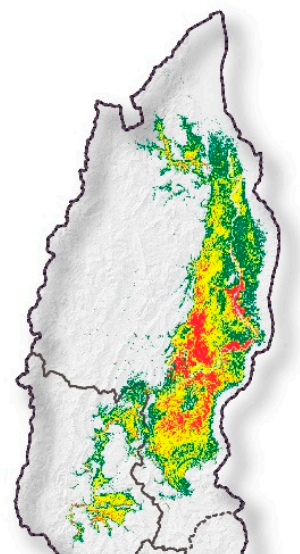

(b) A. leiocarpa

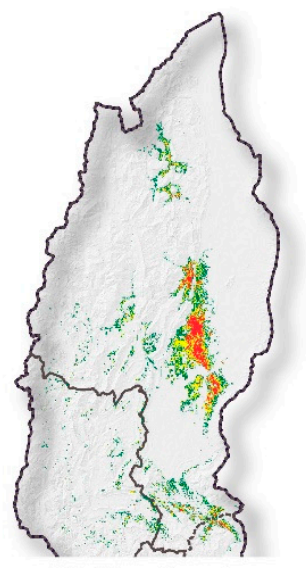

(f) C. odorata

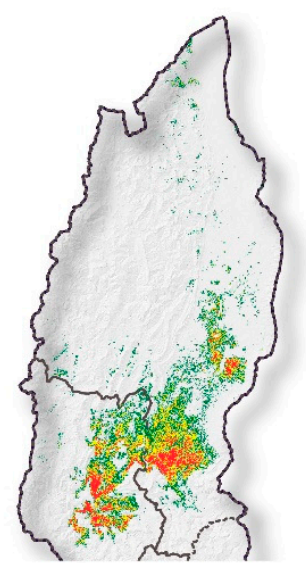

(j) Inga $s p$.

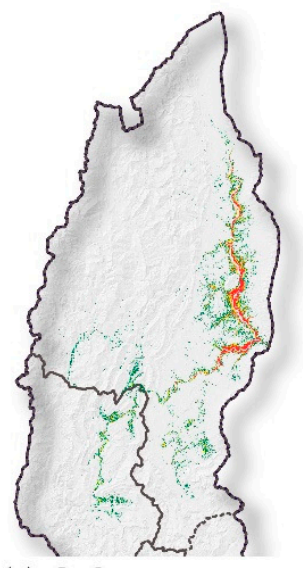

(c) C. Spruceanum

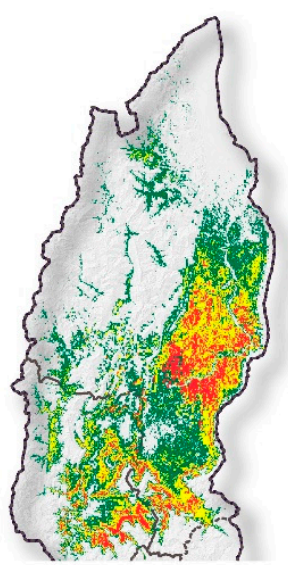

(g) C. cateniformis

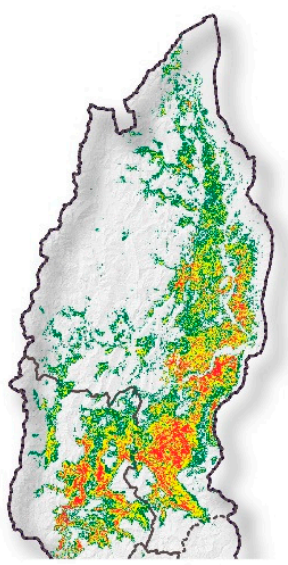

(k) O. parvifolia

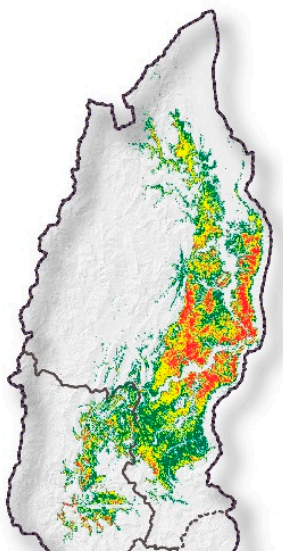

(d) C. decandra

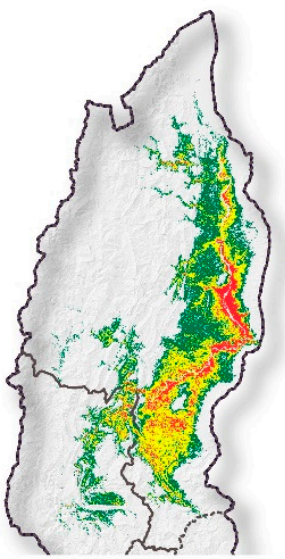

(h) C. pentandra

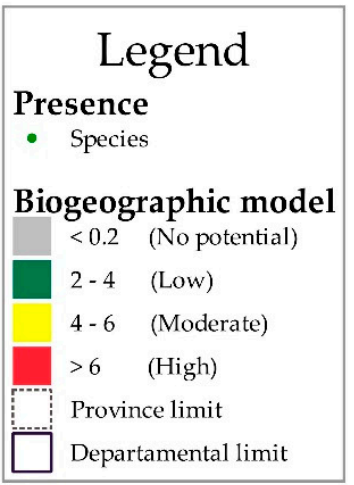

$\stackrel{0}{25} 50 \mathrm{~km}$

Figure 3. (a) The Presence of the Ten Timber Species and (b-k) Biogeographic Distributions of the Ten Timber Species in Amazonas, Peru.

Table 5 describes the surface area $\left(\mathrm{km}^{2}\right)$ of each species by level of potential distribution and the percentage that this surface represents with respect to the total study area $\left(42,050.37 \mathrm{~km}^{2}\right)$. C. montana has the largest total potential distribution range with $17,107.10 \mathrm{~km}^{2}$, covering $40.68 \%$ of the Amazon territory, followed by C. cateniformis with $8619.21 \mathrm{~km}^{2}(20.50 \%)$ and O. parvifolia with $7730.28 \mathrm{~km}^{2}$ $(18.38 \%)$. For their part, C. spruceanum and C. odorata cover only $2.33 \%\left(977.80 \mathrm{~km}^{2}\right)$ and $3.63 \%$ $\left(1527.93 \mathrm{~km}^{2}\right)$, respectively. A total of $14.97 \%\left(6299.79 \mathrm{~km}^{2}\right)$ of the Amazon has conditions to host 
species in coexistence, with a high potential distribution of $3.73 \mathrm{~km}^{2}$ that could support more than six species coexisting together.

Table 5. Potential Biogeographical Distribution Levels of Ten Timber Species in Amazonas, Peru.

\begin{tabular}{ccccccccc}
\hline & \multicolumn{7}{c}{ Potential Distribution } \\
\cline { 2 - 9 } Species & \multicolumn{2}{c}{ High } & \multicolumn{2}{c}{ Moderate } & \multicolumn{2}{c}{ Low } & \multicolumn{2}{c}{ Total } \\
\cline { 2 - 9 } & $\mathbf{k m}^{\mathbf{2}}$ & \% Amazonas & $\mathbf{k m}^{\mathbf{2}}$ & \% Amazonas & $\mathbf{~ k m}^{\mathbf{2}}$ & \% Amazonas & $\mathbf{k m}^{\mathbf{2}}$ & \% Amazonas \\
\hline A. leiocarpa & 761.55 & 1.81 & 2449.89 & 5.83 & 2822.01 & 6.71 & 6033.45 & 14.35 \\
C. spruceanum & 167.52 & 0.40 & 192.64 & 0.46 & 617.64 & 1.47 & 977.8 & 2.33 \\
C. decandra & 761.67 & 1.81 & 1885.82 & 4.48 & 2903.42 & 6.90 & 550.9 & 13.20 \\
C. montana & 2625.42 & 6.24 & 5832.68 & 13.87 & 8649.03 & 20.57 & 17107.1 & 40.68 \\
C. odorata & 210.72 & 0.50 & 423.74 & 1.01 & 893.48 & 2.12 & 1527.93 & 3.63 \\
C.cateniformis & 1194.75 & 2.84 & 2666.85 & 6.34 & 4757.6 & 11.31 & 8619.21 & 20.50 \\
C. pentandra & 584.39 & 1.39 & 1966.59 & 4.68 & 3128.21 & 7.44 & 5679.18 & 13.51 \\
H. crepitans & 411.88 & 0.98 & 890.42 & 2.12 & 1260.59 & 3.00 & 2562.89 & 6.09 \\
Inga sp. & 461.2 & 1.10 & 866.69 & 2.06 & 1542.38 & 3.67 & 1280.27 & 6.83 \\
O. parvifolia & 1000.82 & 2.38 & 2525.53 & 6.01 & 4203.92 & 10.00 & 7730.28 & 18.38 \\
\hline Coexistence & 3.73 & 0.008 & 324.64 & 0.77 & 5971.42 & 14.20 & 6299.79 & 14.97 \\
\hline
\end{tabular}

\subsection{Potential Areas of Restoration and Coexistence of Species}

From the degraded areas identified by the Ministry of the Environment of Peru (Figure 4a) and their intersection with the potential biographical distribution of the ten timber species (Figure $3 b-k$ ), potential restoration areas were identified with each one of these species (Figure $4 b-k$ ). Likewise, the levels of coexistence of the species are presented (Figure 41). In Table 6, three levels of restoration can be distinguished according to each level of potential distribution. In other words, the higher the potential distribution level, the greater the potential for restoration with this species. C. montana $\left(1221.79 \mathrm{~km}^{2}\right)$, O. parvifolia $\left(491.96 \mathrm{~km}^{2}\right)$, and C. cateniformis $\left(449.20 \mathrm{~km}^{2}\right)$, are the species that cover a larger area with high restoration potential. A total of $6.56 \%\left(2758.45 \mathrm{~km}^{2}\right)$ of Amazonas can be restored with the ten species under study, of which six or more species can be installed in a combined way to restore $1.35 \mathrm{~km}^{2}$ of degraded territory in Amazonas.

Table 6. Degraded Areas with Restoration Potential in Amazonas, Peru.

\begin{tabular}{|c|c|c|c|c|c|c|c|c|}
\hline \multirow{2}{*}{ Species } & \multicolumn{8}{|c|}{ Potential for Restoration } \\
\hline & $\mathrm{km}^{2}$ & \% Amazonas & $\mathrm{km}^{2}$ & $\%$ Amazonas & $\mathrm{km}^{2}$ & $\%$ Amazonas & $\mathrm{km}^{2}$ & $\%$ Amazonas \\
\hline A. leiocarpa & 305.07 & 0.73 & 931.18 & 2.21 & 902.75 & 2.15 & 2139.00 & 5.09 \\
\hline C. spruceanum & 70.07 & 0.17 & 88.99 & 0.21 & 269.69 & 0.64 & 428.75 & 1.02 \\
\hline C. decandra & 403.36 & 0.96 & 965.52 & 2.30 & 481.79 & 1.15 & 1850.67 & 4.40 \\
\hline C. cateniformis & 449.20 & 1.07 & 917.02 & 2.18 & 1620.20 & 3.85 & 2986.42 & 7.10 \\
\hline C. pentandra & 297.86 & 0.71 & 880.93 & 2.09 & 986.43 & 2.35 & 2165.22 & 5.15 \\
\hline H. crepitans & 213.54 & 0.51 & 452.09 & 1.08 & 601.97 & 1.43 & 1267.60 & 3.01 \\
\hline Inga sp. & 254.84 & 0.61 & 419.91 & 1.00 & 629.70 & 1.50 & 1304.45 & 3.10 \\
\hline O. parvifolia & 491.96 & 1.17 & 1015.02 & 2.41 & 1291.14 & 3.07 & 2798.12 & 6.65 \\
\hline
\end{tabular}




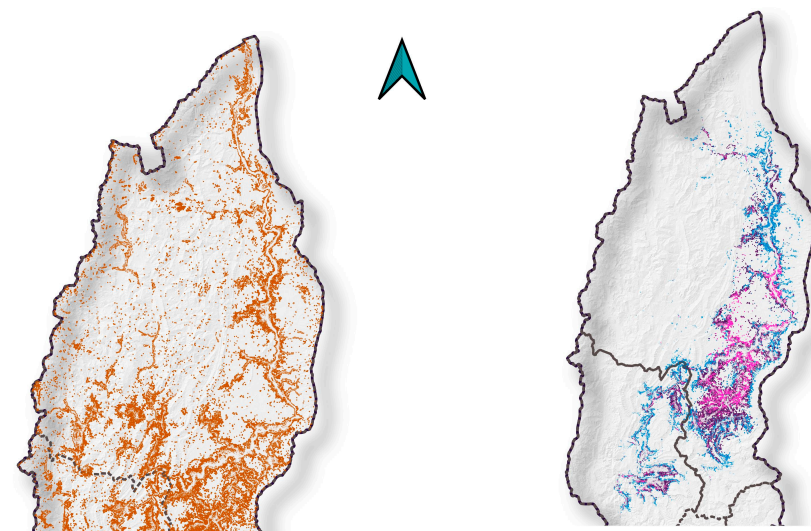

(b) A. leiocarpa

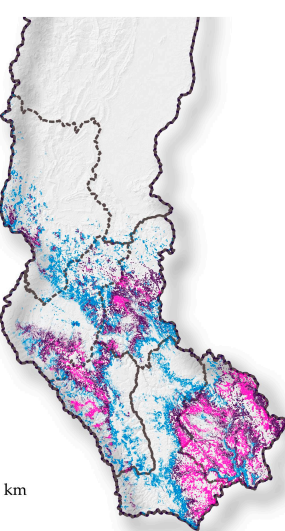

(e) C. montana

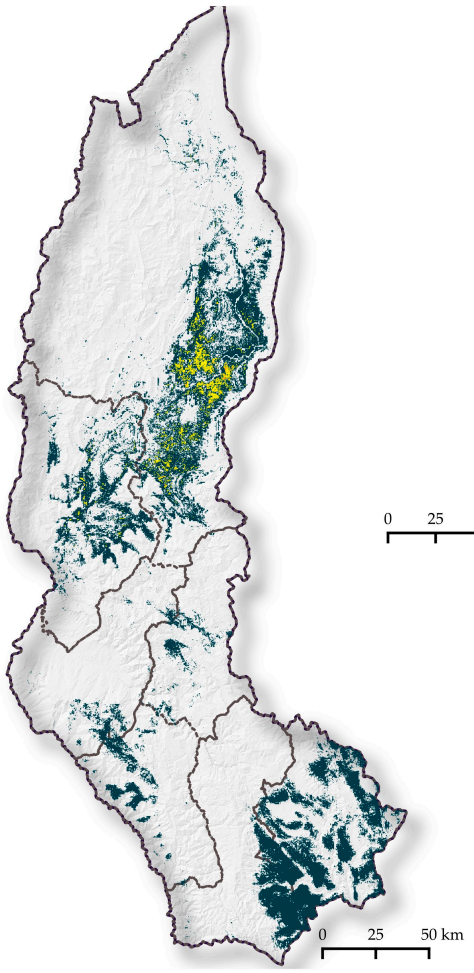

(l) Multiple coexistence of forest species

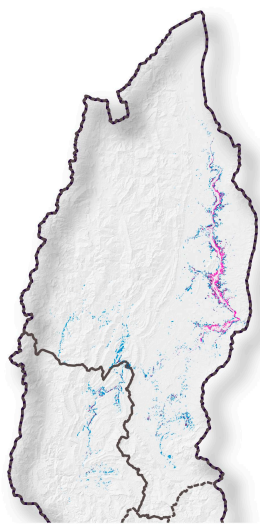

(c) C. Spruceanum

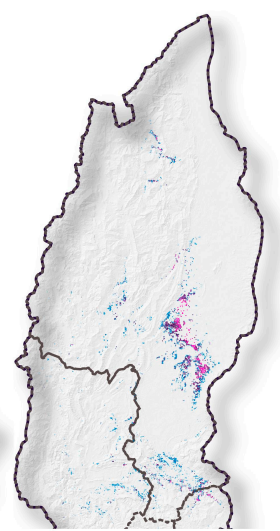

(f) C. odorata

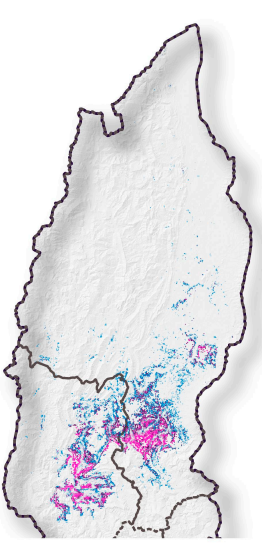

(i) Inga sp.

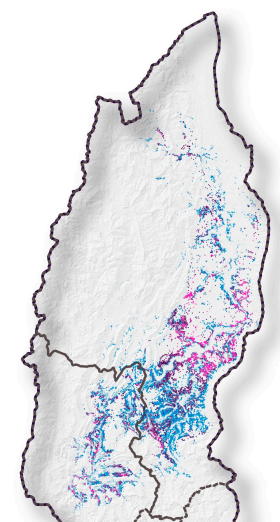

(d) C. decandra

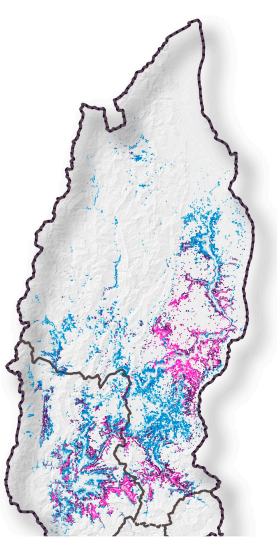

(g) C. cateniformis

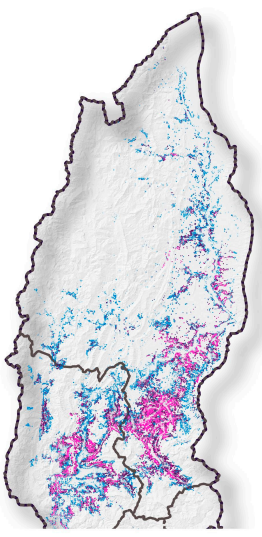

(j) O. parvifolia

(h) C. pentandra

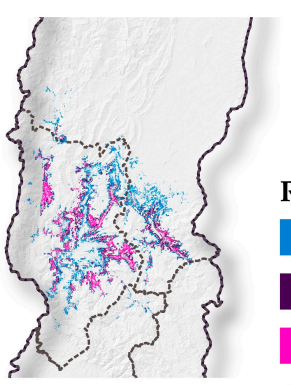

(k) H. crepitans

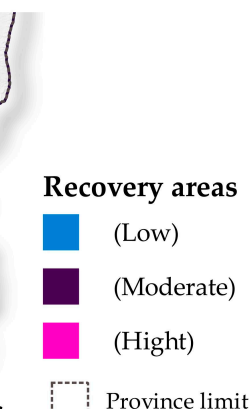

Legend

Degraded areas Coexistence of species

1-3 (Low)

3-6 (Moderate)

$>6$ (Hight)

Departamental limit

Figure 4. (a) Degraded Areas [67]; (b-k) Spatial Distribution of Degraded Areas for Restoration with Forest Species in Amazonas (Peru);(l) Coexistence of Multiple Forest Species. 


\subsection{Potential Biogeographic Distribution in Conservation Areas}

From the high potential distribution of the ten timber species (Figure 3b-k) and their intersection with the Regional Conservation System (Figure 5a), the presence of one or more species within a conservation category was identified (Figure 5b, Table 7). From the highest to lowest efficiency in conserving forests with the evaluated species, the categories are: Conservation Concessions-CC $\left(288.34 \mathrm{~km}^{2}\right)$, Private Conservation Area-PCA (222.06 km²), Reserve Zone (RZ) $\left(209.34 \mathrm{~km}^{2}\right)$, Regional Conservation Area-RCA $\left(140.14 \mathrm{~km}^{2}\right)$, and Protected Natural Area-PNA $\left(46.70 \mathrm{~km}^{2}\right)$. The species A. leiocarpa is the one that is more widely distributed in CC $\left(23.30 \mathrm{~km}^{2}\right)$, C. spruceanum $\left(3.92 \mathrm{~km}^{2}\right)$ and C. decandra (124.82 $\left.\mathrm{km}^{2}\right)$ in Reserve Zone (RZ), C. montana in PCA $\left(220.89 \mathrm{~km}^{2}\right)$, C. odorata $\left(3.94 \mathrm{~km}^{2}\right)$ in PNA, C. cateniformis $\left(42.68 \mathrm{~km}^{2}\right)$ in CC, C. pentandra $\left(16.29 \mathrm{~km}^{2}\right)$ in RZ, H. crepitans $\left(9.61 \mathrm{~km}^{2}\right)$ in CC, Inga sp. $\left(0.30 \mathrm{~km}^{2}\right)$ in PNA, and O. parvifolia $\left(32.33 \mathrm{~km}^{2}\right)$ in RZ. A total of $2.16 \%\left(906.72 \mathrm{~km}^{2}\right)$ of the study area is covered by the distribution of one or more species and in some category of conservation.

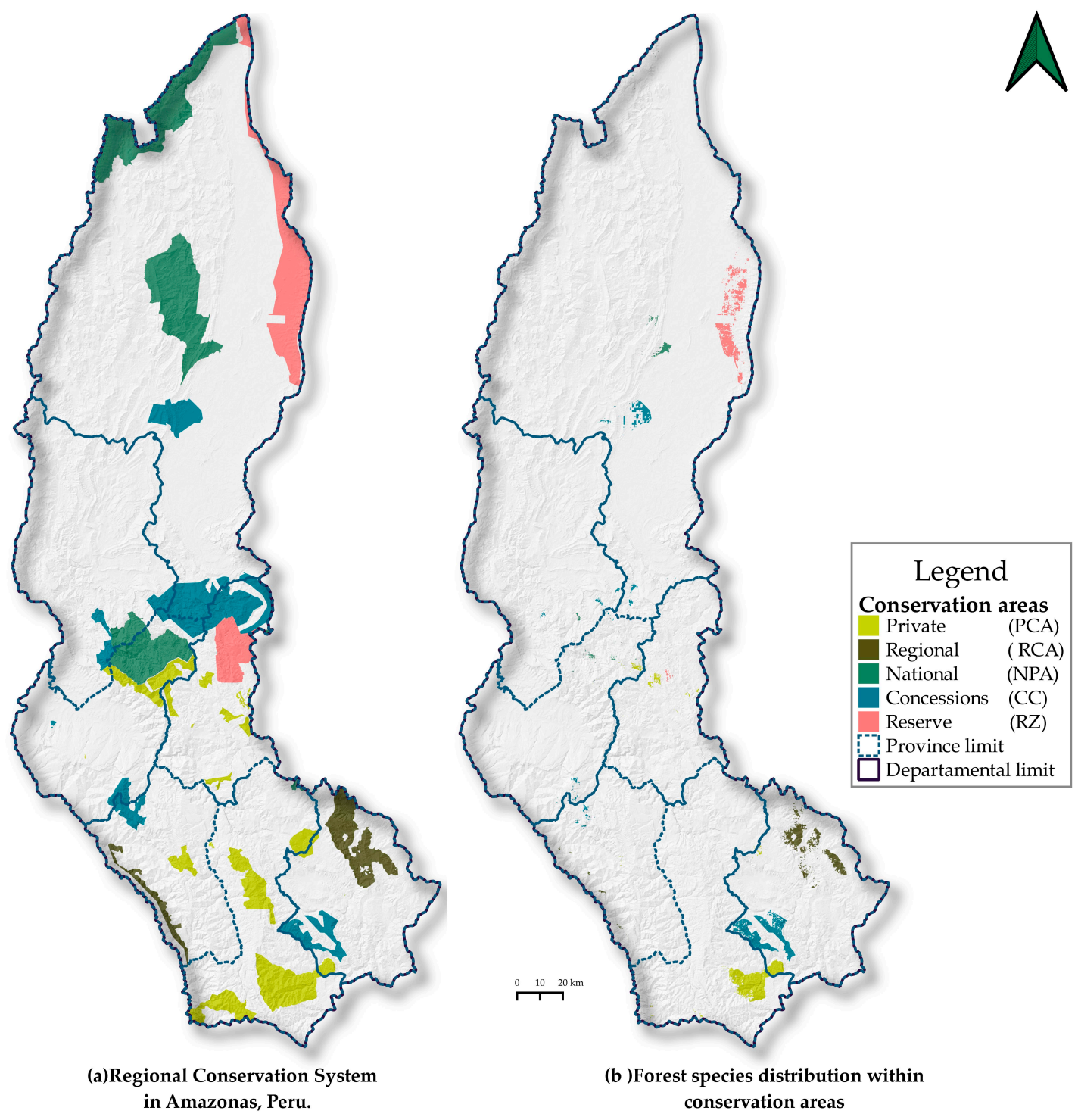

Figure 5. Biogeographic Distribution Areas and Conservation of Forest Species in Amazonas, Peru: (a) Regional Conservation System and (b) Forest Species Distribution within Conservation Areas. 
Table 7. Areas with Potential for Forest Restoration and Their Distribution in the Regional Conservation System of the Region of Amazonas.

\begin{tabular}{|c|c|c|c|c|c|c|c|}
\hline \multirow{3}{*}{ Species } & \multicolumn{7}{|c|}{ High Potential Distribution in the Regional Conservation System } \\
\hline & \multicolumn{5}{|c|}{ Conservation Category } & \multicolumn{2}{|r|}{ Total } \\
\hline & PCA & RCA & PNA & $\mathrm{CC}$ & $\mathbf{R Z}$ & $\mathrm{km}^{2}$ & $\%$ Amazonas \\
\hline A. leiocarpa & & & 4.16 & 23.30 & 4.61 & 32.07 & 0.08 \\
\hline C. spruceanum & & & & & 3.92 & 3.92 & 0.01 \\
\hline C. decandra & 1.17 & & 11.74 & 16.54 & 124.82 & 154.26 & 0.37 \\
\hline C. montana & 220.89 & 140.14 & 8.37 & 185.43 & 3.16 & 557.98 & 1.33 \\
\hline C. odorata & & & 3.94 & 1.76 & & 5.70 & 0.01 \\
\hline C.cateniformis & & & 11.19 & 42.68 & 24.29 & 78.16 & 0.19 \\
\hline C. pentandra & & & & 1.39 & 16.29 & 17.68 & 0.04 \\
\hline H. crepitans & & & 2.39 & 9.61 & & 12.00 & 0.03 \\
\hline Inga sp. & & & 0.30 & 0.16 & & 0.46 & 0.00 \\
\hline O. parvifolia & & & 4.68 & 7.48 & 32.33 & 44.49 & 0.11 \\
\hline Total & 222.06 & 140.14 & 46.7 & 288.34 & 209.34 & 906.72 & 2.16 \\
\hline
\end{tabular}

\section{Discussion}

This study shows the potential biogeographic distribution of ten endangered timber species over the Peruvian Amazonia along with the spatial distribution of degraded areas for restoration with natural forest species through novel MaxEnt modeling techniques using vast amounts of the numerical and remote sensing data. Starting from the revision of the forest management plans, it was possible to locate 4454 georeferenced trees, considering scientific species names and the wood volume [68], which corresponded to ten timber species that were approved through a system of concessions, permits, and authorizations [69], fundamental tools that guarantee the sustainability of forests [70]. In this regard, based on the review of management plans, it was possible to locate 4454 georeferenced trees that corresponded to the ten timber species. Although their distribution is concentrated in the northern part of Amazonas and below $1000 \mathrm{~m}$, we found an exception with C. montana (Figure 3e), whose distribution is above $1500 \mathrm{~m}$, which is well documented by the botanical collections reported for these species [71-73]. This is because elevation has a significant impact on local climate, which influences the vegetation's growth and character [74].

The spatio-temporal distribution represents a major basis for understanding a species and its past, present, and future in order to establish forest management strategies [75]. Our study was based on a Maximum Entropy model, which outperforms other forms of SDM in predictive accuracy and tolerance to sample size when the sample is small [60]. In fact, it uses only present data for modeling [76]. Using bioclimatic (19), topographic (3), edaphic (3), and solar radiation variables [44,51,77], the biogeographic distribution of ten timber species was determined, covering $19.45 \%$ of the total surface of Amazonas. However, it is possible to find species that have the ability to grow outside their natural range, often with better development than in their native zone due to assisted migration programs and climate change [78]. It is, therefore, possible to find trees or plantations outside the potential range of the species presented in this research.

This study relates to national ecological niches for C. spruceanum, C. cateniformis, C. odorata, H. crepitans, and C. integrifolia (actually C. pentandra) [43], as well as the national distribution of C. odorata [79] and Cedrela montana [71,72]. However, species like Ceiba pentandra and Calycophyllum spruceanum can be found in pioneering secondary forests near roads and riverbanks, forming groups called "capironales" [35,72,80]. The potential distribution of Cedrela montana includes some towns such as Florida (Bongará) and Molinopampa (Chachapoyas); meanwhile, Cedrela odorata is found in Chiriaco and El Muyo (Bagua) in northern Amazonas, as reported by Pennington and Muellner [81]. In the same way, the distribution of A. leiocarpa, C. spruceanum, C. decandra (A. decandra), C. odorata, C. cateniformis, C. pentandra, H. crepitans, and Otoba parvifolia, also coincides with the geographical distribution shown 
in forest species identification sheets $[73,82,83]$ and national studies $[71,72,84,85]$. In Peru, Inga sp. has not yet been widely studied [86], including species such as I. marginata, I. bourgonnii, I. tocacheana, I. tessmannii, I. multinervis, I. acreana, I ruiziana, and I. punctate, which are widely distributed in the northern part of the Peruvian Amazonas region [86].

An average of AUC $=0.95$ was achieved, and considering models with "excellent" predictive performance (AUC $=0.914-0.985$ ), these are equal to or more accurate than those reported in the literature for plant species such as Paeonia veitchii (0.958) [55], Paeonia ostii (0.960) [54], Daphne mucronata (0.95) [87], Rosa arabica (0.968 \pm 0.009) [20], Aristolochia gigantea (0.924) [88], Justicia adhatoda (0.923) [57], Garcinia indica (mean $0.959 \pm 0.023)$ [89], Euphorbia antisyphilitica $(0.920 \pm 0.039)$ [90], Abies pindrow $(0.970 \pm 0.019)$, and Betula utilis $(0.984 \pm 0.008)$ [28]. Even the "good" performance of C. montana (AUC $=0.868)$ is equal to or more accurate than those of Quercus sp. [77], Picea smithiana (0.979 \pm 0.005$)$, and Pinus wallichiana (0.974 \pm 0.009$)$ [28]. Regarding model performance, Velazco et al. [91] modeled 125 species of plants at the continental level (neotropical region) and found that the integration of edaphic variables generates models with similar or better precision compared to those built only with climatic variables. Therefore, as in this study, it is recommended to use edaphic variables in the modeling. Therefore, the data set, which includes the timber species modeled, represents valuable information to enrich the national, continental, or even global species database.

Once the distribution of a species is known, it is important to design and complement protection networks to safeguard biodiversity, which is a difficult task for governments and conservationists in megadiverse countries [92]. As a matter of fact, the least protected species are usually the most threatened [93], as is the case of Cedrela odorata L., which is categorized as a vulnerable species (VU) [94]. Therefore, future conservation policies must be considered, taking into account goods and services and promoting a sustainable environment [95]. C. montana is in the endangered category (EN), C. cateniformis and C. pentandra are in the least concern (LC) category, and the other species are not included in the IUCN Red List. Protected areas represent the cornerstone of conservation strategies for protecting biodiversity through in situ approaches [96]. Based on what has been described, the Amazonas region has $18.03 \%$ of its territory under conservation areas (Figure 5a) with biological diversity. This allows for research in slightly altered ecosystems [97], and also strengthens the Regional System of Regional Conservation (SICRE), whose objective is to contribute to the development of the region through the effective management of conservation areas, articulation of national, regional, and private conservation areas, and concessions for conservation [98].

A total of 278,249 hectares of territory have been identified in the region of Amazonas as having high to very high priority for restoration, such as areas suffering from deforestation, soil erosion, forest fires, and illegal logging. However, no plan has been implemented yet [99]. Therefore, it is important to develop restoration actions, as they are a great opportunity to reduce poverty, control the effects of climate change, and protect the environment [100]. Hence, there is an urgent need to practice forest restoration to maintain natural ecosystems [101], which is an important natural solution for mitigating climate change [102]. There is increasing evidence that mixed-species forests can provide multiple ecosystem services [103], combining tree species that can provide multiple ecosystem services at higher levels [104,105]. The coexistence of the ten timber species in Amazonas (Figure 41) allows for the recovery of degraded forests resulting from overharvesting, fires, grazing, or other disturbances or land uses [106] through the establishment of enrichment plantations, natural regeneration management, and agroforestry systems [107], through the combined installation of native wood species with fast (Simarouba amara), medium (Dypterix ferrea), and slow (Swietenia macrophylla) growth, and with nitrogen-fixing species, such as Inga edulis (guaba). The species S. macrophylla "mahogany", C. odorata "cedar", Amburana cearensis "ishpingo", and C. cateniformis "screw" are more competitive with other species during their growth, and they are implemented through silvicultural practices for the regeneration of secondary and degraded forests [108].

Finally, this research provides a basis for future studies on potential areas for other relevant species in order to monitor in situ systems, including the identification of areas with high or low reforestation 
potential, and also to develop forest management strategies [109]. It is also time to encourage efforts to restore and regenerate degraded areas in the region of Amazonas. For this purpose, it is important that reforestation should be a complementary rather than competitive livelihood activity, thus fostering local social equity and analyzing and complementing information that will enable restoration objectives to be achieved [110].

\section{Conclusions}

The forest species with the largest volume of timber granted for logging in the region of Amazonas between 2016 to 2019 were A. leiocarpa "anacaspi", C. spruceanum "capirona", C. decandra "papelillo o cachimbo", C. montana "cedro", C. odorata "cedro amargo", C. cateniformis "tornillo", C. pentandra "lupuna", H. crepitans "catahua", Inga sp. "guabilla", and O. parvifolia "sempo", which are harvested mainly in the territories of native communities (Bagua and Condorcanqui provinces) and private properties (Rodríguez de Mendoza province), with a total timber volume of 37,686.17 cubic meters of roundwood $\left(\mathrm{m}^{3}(\mathrm{r})\right)$.

The biogeographic modeling for the 10 forest species obtained an average AUC of 0.95, which is considered an excellent yield. The species with the greatest range of potential distribution were C. montana ( $40.68 \%$ of the territory), C. Cateniformis (20.50\%), and O. parvifolia (18.38\%). On the other hand, C. spruceanum and C. odorata cover only $2.33 \%$ and $3.63 \%$, respectively. The main limitation of distribution was due to the altitude variable, with the study area presenting an altitudinal range of $120 \mathrm{~m}$ a.s.l. in the north up to $4400 \mathrm{~m}$ a.s.l. in the southern part. Therefore, the greatest biogeographic distribution of the studied species is concentrated in the north of the department of Amazonas and below $1000 \mathrm{~m}$ a.s.l., although we find an exception with C. montana, whose distribution is above $1500 \mathrm{~m}$ a.s.l.

The high biogeographic distribution of one or more species is protected under some category of conservation, and C. montana and C. decandra are the species with the greatest potential distribution ranges in these areas. In addition, it was identified that eight of the ten species can coexist, and the species with the highest percentage of potential restoration area is C. montana (14.57\% of Amazonas). This study was carried out in the Peruvian Amazon; however, it is applicable in other ecosystems, such as tropical and temperate forests, allowing the generation of tools for the sustainable management of forests and promoting the success of forest restoration and conservation.

Supplementary Materials: The following are available online at http://www.mdpi.com/2071-1050/12/19/7945/s1, Supplementary Materials 1. Granting of timber volumes from the Forest and Wildlife Law No. 29763 (1 October 2015) to 2019 in Amazonas, Peru; Supplementary Materials 2. Statistical selection of environmental variables for the modeling of each species in Amazonas, Peru; and Supplementary Materials 3. Jackknife test results of the modeling of each species in Amazonas, Peru.

Author Contributions: Conceptualization, D.A.C.S. and N.B.R.B.; Data curation, D.A.C.S.; Formal analysis, D.A.C.S., N.B.R.B., C.A.A.G. and S.B.; Funding acquisition, M.O. and C.T.G.; Investigation, D.A.C.S., E.B.C., N.B.R.B., M.O., C.T.G., C.A.A.G. and S.B.; Methodology, D.A.C.S., E.B.C., N.B.R.B. and C.A.A.G.; Project administration, E.B.C., M.O., and C.T.G.; Software, D.A.C.S. and N.B.R.B.; Supervision, C.T.G., C.A.A.G. and S.B.; Writing—original draft, D.A.C.S.; Writing-review and editing, D.A.C.S., E.B.C., N.B.R.B., M.O., C.T.G., C.A.A.G., and S.B. All authors have read and agreed to the published version of the manuscript.

Funding: This work was supported by the SNIP project N 316114 “Service Creation Project of the Biodiversity and Conservation of Wild Species Genetic Resources Laboratory at the Toribio Rodríguez de Mendoza National University-Amazonas Region".

Acknowledgments: The authors appreciate and acknowledge the support of the Research Institute for the Sustainable Development of the Eyebrow of the Jungle (INDES-CES) of the National University Toribio Rodriguez de Amazonas (UNTRM).

Conflicts of Interest: The authors declare no conflict of interest. 


\section{References}

1. Flores, Y. Crecimiento y Productividad de Plantaciones Forestales en la Amazonía Peruana; Corporación Grafica Andina SAC: Lima, Peru, 2010.

2. MINAM. Perú Reino de Bosques; Editorial Etiqueta Negra/Pool Editores SAC: Lima, Peru, 2014.

3. Andersen, H.E.; Reutebuch, S.E.; McGaughey, R.J.; d'Oliveira, M.V.N.; Keller, M. Monitoring selective logging in western amazonia with repeat lidar flights. Remote Sens. Environ. 2014, 151, 157-165. [CrossRef]

4. Killick, E. Extractive Relations: Natural Resource Use, Indigenous Peoples and Environmental Protection in Peru. Bull. Lat. Am. Res. 2020, 39, 290-304. [CrossRef]

5. Dourojeanni, M. Aprovechamiento del barbecho forestal en áreas de agricultura migratoria en la Amazonía peruana. Rev. For. Perú 1987, 14, 1-33.

6. Adhikari, D.; Barik, S.K.; Upadhaya, K. Habitat distribution modelling for reintroduction of Ilex khasiana Purk., a critically endangered tree species of northeastern India. Ecol. Eng. 2012, 40, 37-43. [CrossRef]

7. Cánovas, F.; Magliozzi, C.; Mestre, F.; Palazón, J.A.; González-Wangüemert, M. ENiRG: R-GRASS interface for efficiently characterizing the ecological niche of species and predicting habitat suitability. Ecography 2016, 39, 593-598. [CrossRef]

8. Tripathi, P.; Dev Behera, M.; Roy, P.S. Optimized grid representation of plant species richness in India-Utility of an existing national database in integrated ecological analysis. PLoS ONE 2017, 12, e0173774. [CrossRef]

9. Guisan, A.; Thuiller, W. Predicting species distribution: Offering more than simple habitat models. Ecol. Lett. 2005, 8, 993-1009. [CrossRef]

10. Peterson, A.T.; Soberón, J.; Pearson, R.G.; Anderson, R.P.; Martínez-Meyer, E.; Nakamura, M.; Araújo, M.B. Ecological Niches and Geographic Distributions (MPB-49); Princeton University Press: Princeton, NJ, USA, 2011.

11. Fagundes, C.K.; Vogt, R.C.; De Marco Júnior, P. Testing the efficiency of protected areas in the Amazon for conserving freshwater turtles. Divers. Distrib. 2016, 22, 123-135. [CrossRef]

12. Antúnez, P.; Suárez-Mota, M.E.; Valenzuela-Encinas, C.; Ruiz-Aquino, F. The potential distribution of tree species in three periods of time under a climate change scenario. Forests 2018, 9, 628. [CrossRef]

13. Guisan, A.; Zimmermann, N.E. Predictive Habitat Distribution Models in Ecology. Ecol. Model. 2000, 135, 147-186. [CrossRef]

14. Phillips, S.B.; Aneja, V.P.; Kang, D.; Arya, S.P. Maximum entropy modeling of species geographic distributions. Ecol. Model. 2006, 190, 231-259. [CrossRef]

15. Bai, Y.; Wei, X.; Li, X. Distributional dynamics of a vulnerable species in response to past and future climate change: A window for conservation prospects. PeerJ 2018, 2018, 1-25. [CrossRef]

16. Beltramino, A.A.; Vogler, R.E.; Gutiérrez Gregoric, D.E.; Rumi, A. Impact of climate change on the distribution of a giant land snail from South America: Predicting future trends for setting conservation priorities on native malacofauna. Clim. Chang. 2015, 131, 621-633. [CrossRef]

17. Naveda-Rodríguez, A.; Vargas, F.H.; Kohn, S.; Zapata-Ríos, G. Andean Condor (Vultur gryphus) in Ecuador: Geographic Distribution, Population Size and Extinction Risk. PLoS ONE 2016, 11, e0151827. [CrossRef] [PubMed]

18. Alfonso-Corrado, C.; Naranjo-Luna, F.; Clark-Tapia, R.; Campos, J.E.; Rojas-Soto, O.R.; Luna-Krauletz, M.D.; Bodenhorn, B.; Gorgonio-Ramírez, M.; Pacheco-Cruz, N. Effects of environmental changes on the occurrence of Oreomunnea mexicana (Juglandaceae) in a biodiversity hotspot cloud forest. Forests 2017, 8, 261. [CrossRef]

19. Qin, A.; Liu, B.; Guo, Q.; Bussmann, R.W.; Ma, F.; Jian, Z.; Xu, G.; Pei, S. Maxent modeling for predicting impacts of climate change on the potential distribution of Thuja sutchuenensis Franch., an extremely endangered conifer from southwestern China. Glob. Ecol. Conserv. 2017, 10, 139-146. [CrossRef]

20. Abdelaal, M.; Fois, M.; Fenu, G.; Bacchetta, G. Using MaxEnt modeling to predict the potential distribution of the endemic plant Rosa arabica Crép. in Egypt. Ecol. Inform. 2019, 50, 68-75. [CrossRef]

21. Otieno, B.A.; Nahrung, H.F.; Steinbauer, M.J. Where did you come from? Where did you go? Investigating the origin of invasive Leptocybe species using distribution modelling. Forests 2019, 10, 115. [CrossRef]

22. Kariyawasam, C.S.; Kumar, L.; Ratnayake, S.S. Invasive plant species establishment and range dynamics in Sri Lanka under climate change. Entropy 2019, 21, 571. [CrossRef]

23. Xu, X.; Zhang, H.; Yue, J.; Xie, T.; Xu, Y.; Tian, Y. Predicting shifts in the suitable climatic distribution of walnut (Juglans regia L.) in China: Maximum entropy model paves the way to forest management. Forests 2018, 9, 103. 
24. Frey, G.P.; West, T.A.P.; Hickler, T.; Rausch, L.; Gibbs, H.K.; Börner, J. Simulated impacts of soy and infrastructure expansion in the Brazilian Amazon: A maximum entropy approach. Forests 2018, 9, 600. [CrossRef]

25. Elith, J.; Phillips, S.J.; Hastie, T.; Dudík, M.; Chee, Y.E.; Yates, C.J. A statistical explanation of MaxEnt for ecologists. Divers. Distrib. 2011, 17, 43-57. [CrossRef]

26. Xu, D.; Agee, E.; Wang, J.; Ivanov, V.Y. Estimation of Evapotranspiration of Amazon Rainforest Using the Maximum Entropy Production Method. Geophys. Res. Lett. 2019, 46, 1402-1412. [CrossRef]

27. Fonseca, M.G.; Aragão, L.E.O.C.; Lima, A.; Shimabukuro, Y.E.; Arai, E.; Anderson, L.O. Modelling fire probability in the Brazilian Amazon using the maximum entropy method. Int. J. Wildland Fire 2016, 25, 955-969. [CrossRef]

28. Gilani, H.; Arif Goheer, M.; Ahmad, H.; Hussain, K. Under predicted climate change: Distribution and ecological niche modelling of six native tree species in Gilgit-Baltistan, Pakistan. Ecol. Indic. 2020, 111, 106049. [CrossRef]

29. Doland Nichols, J.; Rosemeyer, M.E.; Lynn Carpenter, F.; Kettler, J. Intercropping legume trees with native timber trees rapidly restores cover to eroded tropical pasture without fertilization. For. Ecol. Manag. 2001, 152, 195-209. [CrossRef]

30. Carpenter, F.L.; Nichols, J.D.; Pratt, R.T.; Young, K.C. Methods of facilitating reforestation of tropical degraded land with the native timber tree, Terminalia amazonia. For. Ecol. Manag. 2004, 202, 281-291. [CrossRef]

31. Walentowski, H.; Heinrichs, S.; Hohnwald, S.; Wiegand, A.; Heinen, H.; Thren, M.; Gamarra Torres, O.A.; Sabogal, A.B.; Zerbe, S. Vegetation succession on degraded sites in the Pomacochas Basin (Amazonas, N Peru)-Ecological options for forest restoration. Sustainability 2018, 10, 609. [CrossRef]

32. Lamb, D.; Erskine, P.D.; Parrotta, J.A. Restoration of Degraded Tropical Forest Landscapes. Science 2005, 310, 1628-1632. [CrossRef]

33. Chazdon, R.L. Towards more effective integration of tropical forest restoration and conservation. Biotropica 2019, 51, 463-472. [CrossRef]

34. Cole, R.J.; Holl, K.D.; Zahawi, R.A. Seed rain under tree islands planted to restore degraded lands in a tropical agricultural landscape. Ecol. Appl. 2010, 20, 1255-1269. [CrossRef] [PubMed]

35. Ymber, F.B. Especies Forestales Nativas Para Recuperacion de Areas Degradadas en la Region Ucayali; Imprenta Davidson: Pucallpa, Peru, 2014.

36. Schmidt, I.B.; de Urzedo, D.I.; Piña-Rodrigues, F.C.M.; Vieira, D.L.M.; de Rezende, G.M.; Sampaio, A.B.; Junqueira, R.G.P. Community-based native seed production for restoration in Brazil-The role of science and policy. Plant Biol. 2019, 21, 389-397. [CrossRef] [PubMed]

37. Romijn, E.; Coppus, R.; De Sy, V.; Herold, M.; Roman-Cuesta, R.M.; Verchot, L. Land restoration in Latin America and the Caribbean: An overview of recent, ongoing and planned restoration initiatives and their potential for climate change mitigation. Forests 2019, 10, 510. [CrossRef]

38. Blignaut, J.; Aronson, J.; de Groot, R. Restoration of natural capital: A key strategy on the path to sustainability. Ecol. Eng. 2014, 65, 54-61. [CrossRef]

39. Jacobs, D.F.; Oliet, J.A.; Aronson, J.; Bolte, A.; Bullock, J.M.; Donoso, P.J.; Landhäusser, S.M.; Madsen, P.; Peng, S.; Rey-Benayas, J.M.; et al. Restoring forests: What constitutes success in the twenty-first century? New For. 2015, 46, 601-614. [CrossRef]

40. MINAM. El Perú de los Bosques; MINAM: Lima, Peru, 2011.

41. MINAM. Mapa Nacional de Cobertura Vegetal: Memoria Descriptiva; MINAM: Lima, Peru, 2015; p. 105.

42. GRA; IIAP. Zonificación Ecológica y Económica (ZEE) del Departamento de Amazonas; IIAP: Iquitos, Peru, 2010.

43. OSINFOR. Modelamieto Espacial de Nichos Ecológicos Para la Evaluación de Presencia de Especies Forestales Maderables en la Amazonía Peruana; Punto \& Grafía S.A.C.: Lima, Peru, 2013.

44. Hengl, T.; De Jesus, J.M.; Heuvelink, G.B.M.; Gonzalez, M.R.; Kilibarda, M.; Blagotić, A.; Shangguan, W.; Wright, M.N.; Geng, X.; Bauer-Marschallinger, B.; et al. SoilGrids250m: Global gridded soil information based on machine learning. PLoS ONE 2017, 12, e0169748. [CrossRef]

45. Rojas, N.B.; Cotrina, D.A.; Castillo, E.B.; Oliva, M.; Salas, R. Current and Future Distribution of Five Timber Forest Species in Amazonas, Northeast Peru: Contributions towards a Restoration Strategy. Diversity 2020, 12, 305. [CrossRef] 
46. OSINFOR. Sistema de Información Gerencial del OSINFOR. Reportes Estadísticos: Principales Especies Forestales Maderables Aprobadas. Available online: https://observatorio.osinfor.gob.pe/Estadisticas/Home/ Reportes/1 (accessed on 15 April 2020).

47. Pliscoff, P.; Fuentes, T. Modelación de la distribución de especies y ecosistemas en el tiempo y en el espacio: Una revisión de las nuevas herramientas y enfoques disponibles. Rev. Geogr. Norte Gd. 2011, 48, 61-79. [CrossRef]

48. Scheldeman, X.; van Zonneveld, M. Training Manual on Spatial Analysis of Plant Diversity and Distribution; Bioversity International: Rome, Italy, 2010.

49. OSINFOR. Modelamiento de la Distribución Potencial de 18 Especies Forestales en el Departamento de Loreto; OSINFOR: Lima, Peru, 2016.

50. Stevens, G.C. The latitudinal gradient in geographic range: How so many species coexist in the tropics. Am. Nat. 1989, 133, 240-256. [CrossRef]

51. Fick, S.E.; Hijmans, R.J. WorldClim 2: New 1-km spatial resolution climate surfaces for global land areas. Int. J. Climatol. 2017, 37, 4302-4315. [CrossRef]

52. De Marco, P.; Nobrega, C.C. Evaluating collinearity effects on species distribution models: An approach based on virtual species simulation. PLoS ONE 2018, 13, e0202403. [CrossRef] [PubMed]

53. Dormann, C.F.; Elith, J.; Bacher, S.; Buchmann, C.; Carl, G.; Carré, G.; Marquez, J.R.G.; Gruber, B.; Lafourcade, B.; Leitao, P.J.; et al. Collinearity: A review of methods to deal with it and a simulation study evaluating their performance. Ecography 2013, 36, 027-046. [CrossRef]

54. Zhang, K.; Zhang, Y.; Zhou, C.; Meng, J.; Sun, J.; Zhou, T.; Tao, J. Impact of Climate Factors on Future Distributions of Paeonia Ostii across China Estimated by MaxEnt; Elsevier: Amsterdam, The Netherlands, 2019.

55. Zhang, K.; Zhang, Y.; Tao, J. Predicting the potential distribution of Paeonia veitchii (Paeoniaceae) in China by incorporating climate change into a maxent model. Forests 2019, 10, 190. [CrossRef]

56. Heikkinen, R.K.; Luoto, M.; Araújo, M.B.; Virkkala, R.; Thuiller, W.; Sykes, M.T. Methods and uncertainties in bioclimatic envelope modelling under climate change. Prog. Phys. Geogr. 2006, 30, 751-777. [CrossRef]

57. Yang, X.Q.; Kushwaha, S.P.S.; Saran, S.; Xu, J.; Roy, P.S. Maxent modeling for predicting the potential distribution of medicinal plant, Justicia adhatoda L. in Lesser Himalayan foothills. Ecol. Eng. 2013, 51, 83-87. [CrossRef]

58. Patel, V.R.; Mehta, R.G. Impact of Outlier Removal and Normalization Approach in Modified k-Means Clustering Algorithm. IJCSI Int. J. Comput. Sci. Issues 2011, 8, 331-336.

59. Jaynes, E.T. Information Theory and Statistical Mechanics. Phys. Rev. 1957, 106, 620-630. [CrossRef]

60. Merow, C.; Smith, M.J.; Silander, J.A. A practical guide to MaxEnt for modeling species' distributions: What it does, and why inputs and settings matter. Ecography 2013, 36, 1058-1069. [CrossRef]

61. Manel, S.; Williams, C.; Ormerod, S.J. Evaluating presence-Absence models in ecology: The need to account for prevalence. J. Appl. Ecol. 2001, 38, 921-931. [CrossRef]

62. Hanley, J.A.; McNeil, B.J. The meaning and use of the area under a receiver operating characteristic (ROC) curve. Radiology 1982, 143, 29-36. [CrossRef]

63. Araujo, M.; Pearson, R.; Thuiller, W.; Erhard, M. Validation of species-climate impact models under climate change. Glob. Chang. Biol. 2005, 11, 1504-1513. [CrossRef]

64. Jiménez-Valverde, A. Insights into the area under the receiver operating characteristic curve (AUC) as a discrimination measure in species distribution modelling. Glob. Ecol. Biogeogr. 2012, 21, 498-507. [CrossRef]

65. Phillips, S.J.; Dudík, M. Modeling of species distributions with Maxent: New extensions and a comprehensive evaluation. Ecography 2008, 31, 161-175. [CrossRef]

66. Zhang, L.; Jing, Z.; Li, Z.; Liu, Y.; Fang, S. Predictive modeling of suitable habitats for Cinnamomum Camphora (L.) presl using maxent model under climate change in China. Int. J. Environ. Res. Public Health 2019, 16, 3185. [CrossRef]

67. MINAM. Estudio para la Identificación de Áreas Degradadas y Propuesta de Monitoreo; MINAM: Lima, Peru, 2017.

68. Sears, R.R.; Pinedo-Vasquez, M. Forest Policy Reform and the Organization of Logging in Peruvian Amazonia. Dev. Chang. 2011, 42, 609-631. [CrossRef]

69. Sears, R.R.; Cronkleton, P.; Polo Villanueva, F.; Miranda Ruiz, M.; Pérez-Ojeda del Arco, M. Farm-forestry in the Peruvian Amazon and the feasibility of its regulation through forest policy reform. For. Policy Econ. 2018, 87, 49-58. [CrossRef] 
70. Arce, R. Aproximaciones a la filosofía forestal de la sustentabilidad del manejo forestal en el Perú. Rev. For. Perú 2019, 34, 113. [CrossRef]

71. Reynel, C.; Pennington, T.; Pennington, R.; Flores, C.; Daza, A. Árboles Útiles de la Amazonía Peruana y sus Usos; ICRAF: Lima, Peru, 2003.

72. Reynel, C.; Pennington, T.D.; Pennington, R.T. Árboles del Perú; Imprenta Bellido: Lima, Peru, 2016.

73. OSINFOR. Fichas de Identificación de Especies Forestales Maderables de la Concesión Forestal Industrial Maderera Zapote (IMAZA)", Como Producto del Curso Taller: "V Curso Taller Fortalecimiento de Capacidades a Supervisores Forestales en Aplicación de Criterios Técnicos, Reconocimiento de Especies Maderables y uso de Tecnologías en las Supervisiones; Ficha Técnica; MLB Impresiones: Lima, Peru, 2018; pp. 1-58.

74. Bandopadhyay, S. Does elevation impact local level climate change? An analysis based on fifteen years of daily diurnal data and time series forecasts. Pac. Sci. Rev. A Nat. Sci. Eng. 2016, 18, 241-253. [CrossRef]

75. Godsoe, W.; Franklin, J.; Blanchet, F.G. Effects of biotic interactions on modeled species' distribution can be masked by environmental gradients. Ecol. Evol. 2017, 7, 654-664. [CrossRef]

76. Elith, J.; Graham, C.H.; Anderson, R.P.; Dudík, M.; Ferrier, S.; Guisan, A.; Hijmans, R.J.; Huettmann, F.; Leathwick, J.R.; Lehmann, A.; et al. Novel methods improve prediction of species' distributions from occurrence data. Ecography 2006, 29, 129-151. [CrossRef]

77. Roces-Díaz, J.V.; Jiménez-Alfaro, B.; Álvarez-Álvarez, P.; Álvarez-García, M.A. Environmental niche and distribution of six deciduous tree species in the spanish atlantic region. IForest 2014, 8, 214-221. [CrossRef]

78. Boiffin, J.; Badeau, V.; Bréda, N. Species distribution models may misdirect assisted migration: Insights from the introduction of Douglas-fir to Europe: Insights. Ecol. Appl. 2017, 27, 446-457. [CrossRef] [PubMed]

79. Laurente, M. Modeling the Effects of Climate Change on the Distribution of Cedrela odorata L. "Cedro" in the Peruvian Amazon. Biologist 2015, 13, 213-224.

80. OSINFOR. Fichas de Identificación de Especies Forestales Maderables y Silvicultura Tropical", Como Producto del IV Curso-Taller: "Fortalecimiento de las Capacidades en la Identificación de Especies Forestales Maderables y Silvicultura Tropical". Dirigido a Supervisores Forestales y de Fauna Silvestre; Ficha Técnica; MLB Impresiones: Lima, Peru, 2017; pp. 1-51.

81. Pennington, T.; Muellner, A.N.; Wise, R. A Monograph of Cedrela (Meliaceae); Dh Books: Milborne Port, UK, 2010.

82. OSINFOR. Fichas de Identificación de Especies Forestales Maderables de la Selva Central", Como Producto del III Curso Taller: "Identificación de Especies Forestales Maderables; Ficha Técnica; Vistay Publicidad E.I.R.L.: Lima, Peru, 2015; pp. 1-69.

83. OSINFOR. Ficha de Identificación de Especies Forestales Maderables de la Provincia de Tahuamanu, Departamento de Madre de Dios; Ficha Técnica; OSINFOR: Lima, Peru, 2019; pp. 1-59.

84. Pennington, T.D.; Reynel, C.; Daza, A. Illustrated Guide to the Trees of Peru; David Hunt: Totnes, UK, 2004.

85. Vásquez, R. Flórula de las Reservas Biológicas de Iquitos, Perú: Allpahuayo-Mishana, Explornapo Camp, Explorama Lodge; Missouri Botanical Garden: Iquitos, Peru, 1997.

86. Reynel, C.; Pennington, T.D. El Género Inga en el Perú: Morfología, Distribución y Usos; Royal Botanic Gardens: Lima, Peru, 1997.

87. Abolmaali, S.M.R.; Tarkesh, M.; Bashari, H. MaxEnt modeling for predicting suitable habitats and identifying the effects of climate change on a threatened species, Daphne mucronata, in central Iran. Ecol. Inform. 2018, 43, 116-123. [CrossRef]

88. Hipólito, J.; Hasui, É.; Viana, B.F. Solving problems involving the distribution of a species of unknown distribution via ecological niche modeling. Nat. Conserv. 2015, 13, 15-23. [CrossRef]

89. Pramanik, M.; Paudel, U.; Mondal, B.; Chakraborti, S.; Deb, P. Predicting climate change impacts on the distribution of the threatened Garcinia indica in the Western Ghats, India. Clim. Risk Manag. 2018, 19, 94-105. [CrossRef]

90. Bañuelos-Revilla, J.E.; Palacio-Núñez, J.; Martínez-Montoya, J.F.; Olmos-Oropeza, G.; Flores-Cano, J.A. Potential distribution and abundance of candelilla (Euphorbia antisyphilitica) in northern zacatecas, mexico. Madera Bosques 2019, 25, e2511657.

91. Velazco, S.J.E.; Galvão, F.; Villalobos, F.; De Marco, P. Using worldwide edaphic data to model plant species niches: An assessment at a continental extent. PLoS ONE 2017, 12, e0186025. [CrossRef]

92. Rodriguez, L.O.; Young, K.R. Biological diversity of Peru: Determining priority areas for conservation. Ambio 2000, 29, 329-337. [CrossRef] 
93. Fajardo, J.; Lessmann, J.; Bonaccorso, E.; Devenish, C.; Muñoz, J. Combined use of systematic conservation planning, species distribution modelling, and connectivity analysis reveals severe conservation gaps in a megadiverse country (Peru). PLoS ONE 2014, 9, e0114367. [CrossRef]

94. Mark, J.; Rivers, M.C. Cedrela Odorata, Spanish Cedar The IUCN Red List of Threatened Species; IUCN: Gland, Switzerland, 2017.

95. Durán, A.P.; Casalegno, S.; Marquet, P.A.; Gaston, K.J. Representation of ecosystem services by terrestrial protected areas: Chile as a case study. PLoS ONE 2013, 8, e0082643. [CrossRef] [PubMed]

96. Possingham, H.P.; Wilson, K.A.; Andelman, S.J.; Vynne, C.H.; Vynme, C.H. Protected areas: Goals, limitations, and design. In Principles of Conservation Biology; Sinauer Associates: Sunderland, MA, USA, 2006; pp. 509-551.

97. Dourojeanni, M.J. Protected areas and scientific research in Peru. Rev. For. Perú 2018, 33, 91-101.

98. Romo, M.; Leo, M.; Epiquién, M. SICRE-AMAZONAS; APECO: Chachapoyas, Peru, 2009.

99. Román, F.; Mamani, A.; Cruz, A.D.; Sandoval, C.; Cuesta, F. Orientaciones para la Restauración de Ecosistemas Forestales y Otros Ecosistemas de Vegetación Silvestre; SERFOR: Lima, Peru, 2018.

100. Laestadius, L.; Maginnis, S.; Minnemeyer, S.; Potapov, P.; Saint-Laurent, C.; Sizer, N. Mapa de oportunidades de restauración del paisaje forestal. Unasylva 2011, 62, 47-48.

101. Burnett, K.M.; Ticktin, T.; Bremer, L.L.; Quazi, S.A.; Geslani, C.; Wada, C.A.; Kurashima, N.; Mandle, L.; Pascua, P.; Depraetere, T.; et al. Restoring to the future: Environmental, cultural, and management trade-offs in historical versus hybrid restoration of a highly modified ecosystem. Conserv. Lett. 2019, 12, e12606. [CrossRef]

102. Griscom, B.W.; Adams, J.; Ellis, P.W.; Houghton, R.A.; Lomax, G.; Miteva, D.A.; Schlesinger, W.H.; Shoch, D.; Siikamäki, J.V.; Smith, P.; et al. Natural climate solutions. Proc. Natl. Acad. Sci. USA 2017, 114, 11645-11650. [CrossRef] [PubMed]

103. Schnabel, F.; Schwarz, J.A.; Dănescu, A.; Fichtner, A.; Nock, C.A.; Bauhus, J.; Potvin, C. Drivers of productivity and its temporal stability in a tropical tree diversity experiment. Glob. Chang. Biol. 2019, 25, 4257-4272. [CrossRef]

104. Gamfeldt, L.; Snäll, T.; Bagchi, R.; Jonsson, M.; Gustafsson, L.; Kjellander, P.; Ruiz-Jaen, M.C.; Fröberg, M.; Stendahl, J.; Philipson, C.D.; et al. Higher levels of multiple ecosystem services are found in forests with more tree species. Nat. Commun. 2013, 4, 1340. [CrossRef]

105. Van Der Plas, F.; Manning, P.; Soliveres, S.; Allan, E.; Scherer-Lorenzen, M.; Verheyen, K.; Wirth, C.; Zavala, M.A.; Ampoorter, E.; Baeten, L.; et al. Biotic homogenization can decrease landscape-scale forest multifunctionality. Proc. Natl. Acad. Sci. USA 2016, 113, 3557-3562. [CrossRef]

106. IITO. ITTO Guidelines for the Restoration, Management and Rehabilitation of Degraded and Secondary Tropical Forests; Internaitonal Tropical Timber Organization: Yokohama, Japan, 2002.

107. Rodríguez, J.C.; Sabogal, C. Restoring degraded forest land with native tree species: The experience of "Bosques Amazónicos" in Ucayali, Peru. Forests 2019, 10, 851. [CrossRef]

108. Nalvarte, W.; Sabogal, C.; Galvan, O.; Marmillod, D.; Angulo, W.; Cordova, N.; Colan, V. Silvicultura en la Amazonia Peruana: Diagnostico de Experiencias en la Region Ucanyali y la Provincia de Puerto Inca; CIFOR: Ucayali, Peru, 2004.

109. Pecchi, M.; Marchi, M.; Burton, V.; Giannetti, F.; Moriondo, M.; Bernetti, I.; Bindi, M.; Chirici, G. Species distribution modelling to support forest management. A literature review. Ecol. Model. 2019, 411, 108817. [CrossRef]

110. Dos Santos, V.A.H.F.; Ferreira, M.J. Initial establishment of commercial tree species under enrichment planting in a Central Amazon secondary forest: Effects of silvicultural treatments. For. Ecol. Manag. 2020, 460, 117822. [CrossRef]

(C) 2020 by the authors. Licensee MDPI, Basel, Switzerland. This article is an open access article distributed under the terms and conditions of the Creative Commons Attribution (CC BY) license (http://creativecommons.org/licenses/by/4.0/). 